
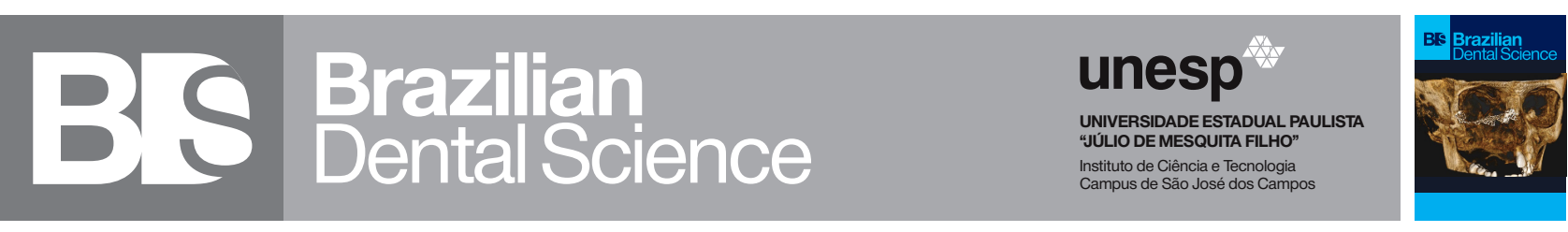

\title{
Schinus terebinthifolius (Brazilian Peppertree) extract used as antifungal to control Candida spp. in planktonic cultures and biofilms
}

\author{
Extrato de Schinus terebinthifolius (pimenta rosa) utilizado como antifúngico para controlar Candida spp. em culturas \\ planctônicas e biofilmes \\ Daiane de Jesus VIEGAS ${ }^{1}$, Isabela AMÊNDOLA ${ }^{2}$, Tássia Marchetti BOTREL ${ }^{3}$, Felipe Eduardo de OLIVEIRA ${ }^{4}$, Leandro Wagner \\ FIGUEIRA $^{3}$, Fábia Lugli SPER ${ }^{3}$, Jonatas Rafael de OLIVEIRA ${ }^{5}$, Luciane Dias de OLIVEIRA ${ }^{3}$ \\ 1 - Federal University of Rio de Janeiro (UFRJ) - Institute of Biodiversity and Sustainability (NUPEM) - Macaé - RJ - Brazil. \\ 2 - University of Taubaté (UNITAU) - Basic Institute of Biosciences - Taubaté - SP - Brazil. \\ 3 - São Paulo State University (UNESP) - Institute of Science and Technology - São José dos Campos - SP - Brazil. \\ 4 - University Center Brazcubas - Brazcubas Faculty of Dentistry - Mogi das Cruzes - SP - Brazil. \\ 5 - Anhembi Morumbi University - School of Medicine - São José dos Campos - SP - Brazil.
}

\begin{abstract}
Objective: The use of medicinal plants may be an alternative method for the control of Candida spp. responsible for human infections. This study evaluated the antifungal effect of Schinus terebinthifolius extract (Brazilian Peppertree) on C. albicans, C. dubliniensis, C. glabrata, and C. krusei planktonic cultures and biofilms. Material and Methods: Minimum inhibitory concentration (MIC) and minimum fungal concentration (MFC) of the plant extract were determined by the broth microdilution method. Biofilms formed in microplate wells were exposed to the extract for $5 \mathrm{~min}$ (50, 100 and $200 \mathrm{mg} / \mathrm{mL})$ or $24 \mathrm{~h}(25,50$ and $100 \mathrm{mg} / \mathrm{mL})$. After determination of colony-forming units per milliliter $(\mathrm{CFU} / \mathrm{mL})$, the data were analyzed by one-way ANOVA and Tukey's Test $(\mathrm{P} \leq 0.05)$. Results: Different MIC $(\mathrm{mg} / \mathrm{mL})$ were found, such as 0.39 (C. dubliniensis), 1.56 (C. albicans), and 3.13 (C. glabrata and C. krusei). Besides, MFC (mg/mL) of 0.78 (C. dubliniensis) and 3.13 (C. albicans, C. glabrata and C. krusei) were also observed. Regarding the biofilms, significant reductions $\left(\log _{10}\right)$ were found after $5 \mathrm{~min}$ and $24 \mathrm{~h}$ exposure to the plant extract, compared to the control group. However, C. dubliniensis was significantly affected only in $24 \mathrm{~h}$ treatment. Conclusion: S. terebinthifolius extract presented a significant antifungal effect on $C$. albicans, C. dubliniensis, C. glabrata, and C. Krusei both in planktonic cultures and biofilms.
\end{abstract}

\section{KEYWORDS}

Biofilms; Brazilian peppertree; Candida; Planktonic cultures; Schinus terebinthifolius.

\section{RESUMO}

Objetivo: O uso de plantas medicinais pode ser um método alternativo para o controle de Candida spp. responsáveis por infecções humanas. Este estudo avaliou o efeito antifúngico do extrato de Schinus terebinthifolius (pimenta rosa) sobre culturas planctônicas e biofilmes de C. albicans, C. dubliniensis, C. glabrata e C. krusei. Material e Métodos: Concentração inibitória mínima (CIM) e concentração fungicida mínima (CFM) do extrato vegetal foram determinadas pelo método de microdiluição em caldo. Biofilmes formados em poços de microplacas foram expostos ao extrato por $5 \mathrm{~min}$ (50, 100 e $200 \mathrm{mg} / \mathrm{mL}$ ) ou $24 \mathrm{~h}(25,50$ e $100 \mathrm{mg} / \mathrm{mL})$. Após determinação de unidades formadoras de colônias por mililitro (UFC/mL), os dados foram analisados por one-way ANOVA e Teste de Tukey $(P \leq 0,05)$. Resultados: Foram encontradas diferentes CIM (mg/mL), como 0,39 (C. dubliniensis), 1,56 (C. albicans) e 3,13 (C. glabrata e C. krusei). Além disso, CFM (mg/mL) de 0,78 (C. dubliniensis) e 3,13 (C. albicans, C. glabrata e C. krusei) também foram observadas. Em relação aos biofilmes, foram encontradas reduções significativas $\left(\log _{10}\right)$ após $5 \mathrm{~min}$ e $24 \mathrm{~h}$ de exposição ao extrato vegetal, em comparação ao grupo controle. No entanto, C. dubliniensis foi significativamente afetada apenas no tratamento de $24 \mathrm{~h}$. Conclusão: O extrato de $S$. terebinthifolius apresentou efeito antifúngico significativo sobre C. albicans, C. dubliniensis, C. glabrata e C. Krusei, tanto em culturas planctônicas quanto em biofilmes.

\section{PALAVRAS-CHAVE}

Biofilmes; Candida; Culturas planctônicas; Pimenta rosa; Schinus terebinthifolius. 


\section{INTRODUCTION}

Y easts, such as Candida, have been continuously responsible for the majority of fungal infections [1]. Species such as $C$. albicans, C. dubliniensis, C. glabrata and C. krusei are considered commensal, belonging to the resident microbiota of oral, genital, urinary and gastrointestinal mucosa [2]. However, these species are opportunistic and can cause local and systemic infections with potentially high mortality rates, usually in patients hospitalised due to candidemia. These fungal infections may be related to the host's health condition as there is a direct relationship with the use of immunosuppressants or antibiotics, disruption of mucosal barrier, radiotherapy and chemotherapy [3-5].

Candida pathogenicity is associated with its capacity to form hyphae, which can favour the invasion of the host's tissues, formation of biofilm on biotic and abiotic surfaces and production of hydrolytic enzymes such as proteases and phospholipases [4].

There are several antifungal agents commercially available for treatment of candidiasis, such as nystatin, amphotericin B, clotimazole, miconazole, itraconazole, fluconazole and ketoconazole. However, these drugs may produce adverse effects such as bitter taste, allergic reactions and resistant cell selection [6].

S. terebinthifolius (Brazilian Peppertree), Anacardiaceae family, is a native species from the South and Central America, but it can also be found in tropical and subtropical regions of the United States and Africa. In Brazil, this plant species is distributed throughout the country's eastern coast, from northern to southern region [7]. Antimicrobial, anti-inflammatory and antifungal activities of this plant have been reported $[7,8]$.

The search for therapeutic applications using medicinal plants and their derivatives has been increasing around the world. The use of products obtained from these plants such as extracts, dyes, essential oils and phytocompounds may be an important alternative for control of strains resistant to the antimicrobial drugs available, as well as for treatment of infections caused by Candida spp. Therefore, this study evaluated the antifungal effect of $S$. terebinthifolius extract on C. albicans, C. dubliniensis, C. glabrata and C. krusei both in planktonic cultures and biofilms.

\section{MATERIAL AND METHODS}

\section{Plant extract}

S. terebinthifolius glycolic extract was commercially obtained at $200 \mathrm{mg} / \mathrm{mL}$, in propylene glycol (All Chemistry, São Paulo, Brazil).

\section{Fungal strains}

Reference strains (ATCC - American Type Culture Collection) of C. albicans (ATCC 18804), C. dubliniensis (ATCC MYA646), C. glabrata (ATCC 9030) and C. krusei (ATCC 6258) were used. The strains were acquired from Laboratory of Microbiology and Immunology, UNESP/ICT, and stored in yeast extract peptone dextrose broth (YPD - Himedia, Mumbai, India) containing $16 \%$ glycerol at $-80^{\circ} \mathrm{C}$.

\section{cultures}

Antifungal activity on planktonic

For determination of MIC, the broth microdilution method was used according to Clinical and Laboratory Standards Institute (CLSI) [9,10]. Fungal suspensions were prepared in sterile saline solution $(0.9 \%$ $\mathrm{NaCl}$ ) from a culture incubated at $37^{\circ} \mathrm{C}$ for $24 \mathrm{~h}$ and standardised to $10^{6} \mathrm{CFU} / \mathrm{mL}$ in a spectrophotometer (Micronal, São Paulo, Brazil). From this suspension were performed two dilutions, one of 1:50 and other of 1:20, in order to obtain a concentration of approximately 
$5 \times 10^{2}$ to $2.5 \times 10^{3} \mathrm{CFU} / \mathrm{mL}$. The assay was performed in microplates with addition of $100 \mu \mathrm{L} /$ well of culture medium and $100 \mu \mathrm{L}$ of extract only in the first well from where 10 serial dilutions were obtained, then $100 \mu \mathrm{L} /$ well of standardised yeast suspension were added. Negative control composed by inoculum and culture medium and positive control constituted only by culture medium were added. The culture medium used was RPMI 1640 (Himedia) with glutamine, without bicarbonate and phenol red indicator, buffered to $\mathrm{pH} 7,0 \pm 0,1$ with MOPS [3(N-morpholino) propanesulfonic acid] (SigmaAldrich, St. Louis, USA). After 24 h incubation, MIC was determined in the first well that showed no turbidity. For determination of MFC, $100 \mu \mathrm{L}$ of MIC and adjacent concentrations were seeded in Sabouraud dextrose (SD - Himedia) agar. After $48 \mathrm{~h}$ incubation at $37^{\circ} \mathrm{C}$ the $\mathrm{MFC}$ was determined on the plaque with no colonial growth.

\section{Antifungal activity on biofilms}

Monomicrobial biofilms were formed in 96-well plates (TPP, Trasadingen, Switzerland). Initially, the yeasts were cultured in SD agar and then in yeast nitrogen base (YNB - Himedia) supplemented with $100 \mathrm{mM}$ of glucose at $37^{\circ} \mathrm{C}$ for $24 \mathrm{~h}$ each one. Posteriorly, the fungal suspension was centrifuged (358 $\mathrm{g} / 10 \mathrm{~min}$ ) and the supernatant disregarded and the pellet suspended in sterile saline solution. After another centrifugation, the suspension was standardised to $10^{7} \mathrm{CFU} / \mathrm{mL}$ in spectrophotometer (Micronal, São Paulo, Brazil). After, $200 \mu \mathrm{L} /$ well of this suspension was added in the microplate and followed to incubation $\left(37^{\circ} \mathrm{C}\right)$ under shaking (75 rpm) for $90 \mathrm{~min}$, for adherence of the biofilms. The supernatant was discarded and YNB broth was added. After $48 \mathrm{~h}$, the biofilms were exposure to the extract for $5 \mathrm{~min}$ at 50 ,
100 and $200 \mathrm{mg} / \mathrm{mL}$; or, for $24 \mathrm{~h}$ at 25, 50 and $100 \mathrm{mg} / \mathrm{mL}$. Saline solution $(0.9 \% \mathrm{NaCl})$ and culture medium were used as controls on the treatments of $5 \mathrm{~min}$ and $24 \mathrm{~h}$, respectively. The biofilm was washed three times with sterile saline solution before being disaggregated by ultrasonic homogenizer (Sonopuls HD 2200 - Bandelin Eletronic, Berlin, Germany) with power of $25 \%$ for 30 s. The suspension was serially diluted and $20 \mu \mathrm{L}$ were added to SD agar in single drops in triplicate. After $48 \mathrm{~h}$ incubation, the concentration of $\mathrm{CFU} / \mathrm{mL}$ was determined by calculating the mean CFU of each drop multiplied by 50 and dilution factor used and the values were converted in $\log ^{10}$. Three assays were performed on an independent basis, with four repetitions each, totalising 12 for each experimental group.

\section{Statistical analysis}

Results were analysed by ANOVA and Tukey's Test ( $\mathrm{P} \leq 0.05)$, using GraphPad Prism software version 5.0.

\section{RESULTS}

In planktonic cultures, MIC $(\mathrm{mg} / \mathrm{mL})$ of 1.56 (C. albicans), 0.39 (C. dubliniensis) and 3.13 (C. glabrata and C. krusei) and MFC of 0.78 (C. dubliniensis) and 3.13 (C. albicans, C. glabrata and C. krusei) were observed.

Regarding the biofilms, this plant extract at 50,100 , and $200 \mathrm{mg} / \mathrm{mL}$ produced significant reductions of $\mathrm{CFU} / \mathrm{mL}$ after $5 \mathrm{~min}$ exposure (Figure 1) in relation to the control group, except C. dubliniensis, when applied the concentrations of 100 and $50 \mathrm{mg} / \mathrm{mL}$. After $24 \mathrm{~h}$ exposure to the extract at 25, 50 and $100 \mathrm{mg} / \mathrm{mL}$, significant reductions of all fungal species were observed (Figure 2). 
C. albicans

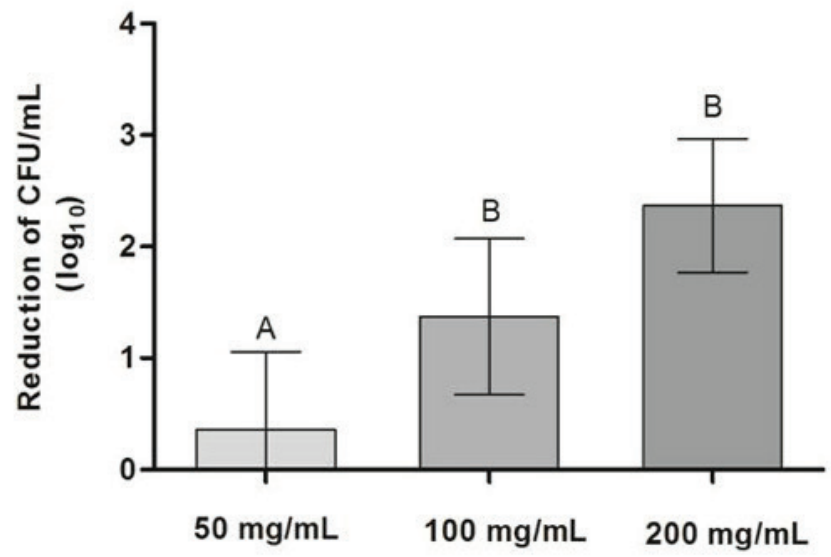

C. glabrata

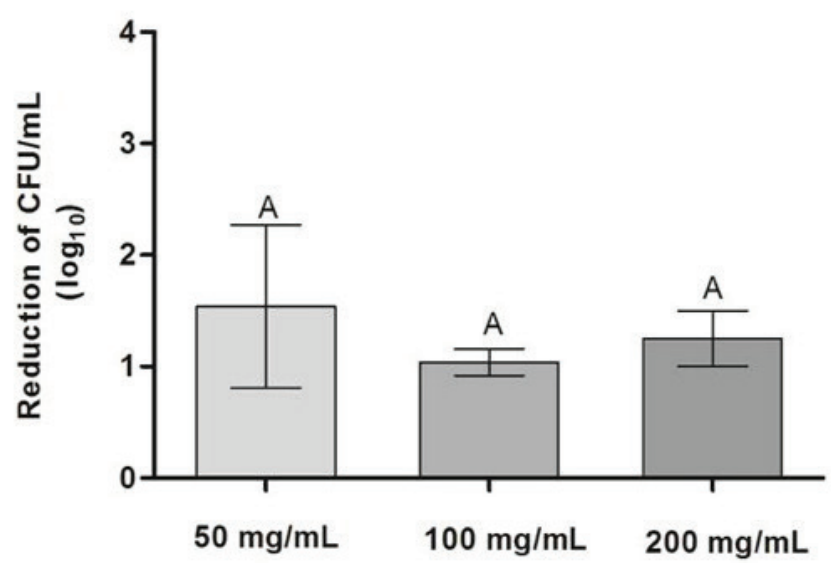

\section{C. dubliniensis}

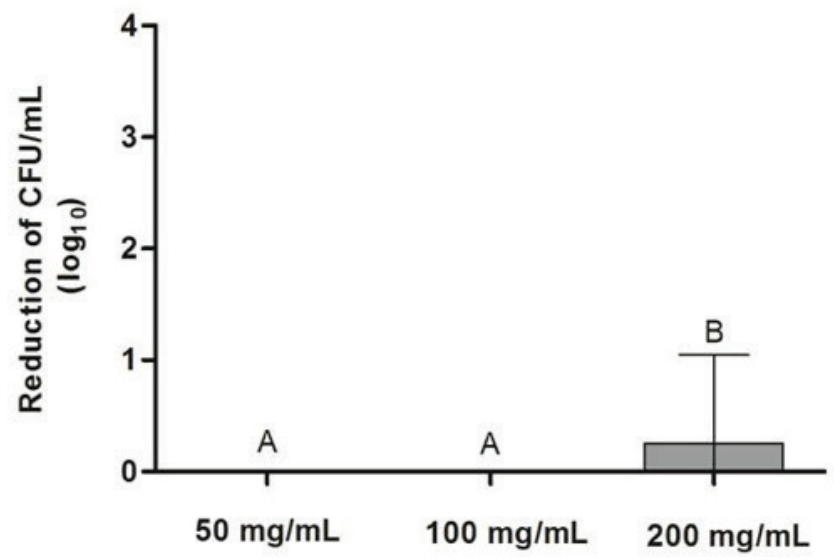

C. krusei

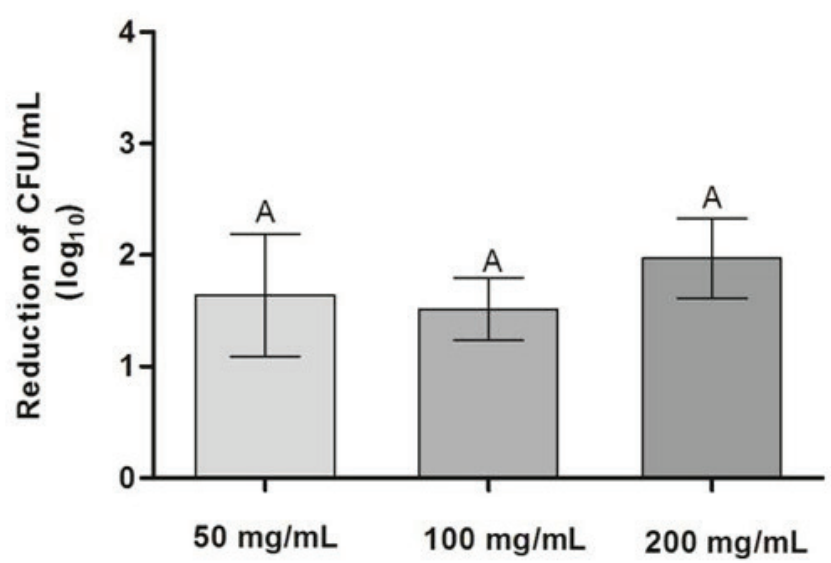

Figure 1 - Mean values ( \pm standard deviation) of reductions (CFU/mL $-\log _{10}$ ) of C. albicans, C. dubliniensis, C. glabrata and C. krusei biofilms obtained after 5 min exposure at 50,100 and $200 \mathrm{mg} / \mathrm{mL}$ of $S$. terebinthifolius extract, regarding to the control group. Different letters indicate significant statistical difference ( $n=12$; one-way ANOVA and Tukey's test, $P \leq 0.05)$. 
C. albicans

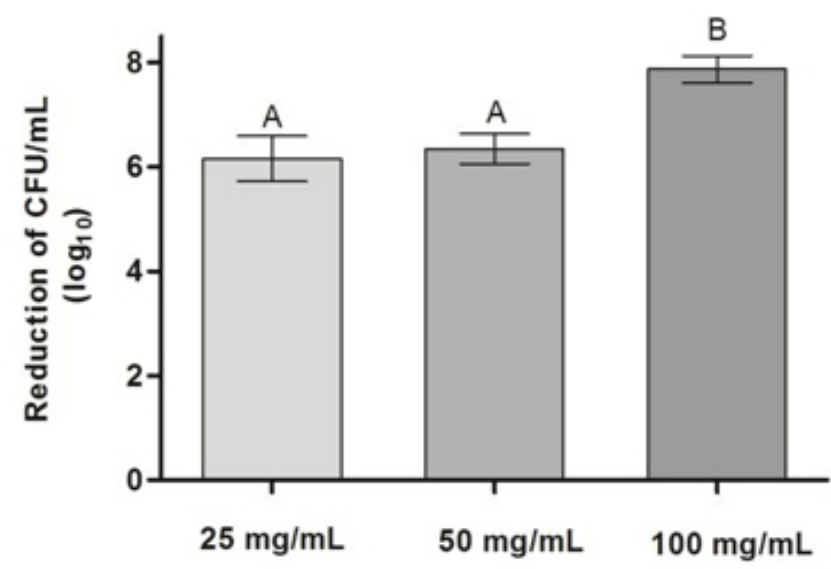

C. glabrata

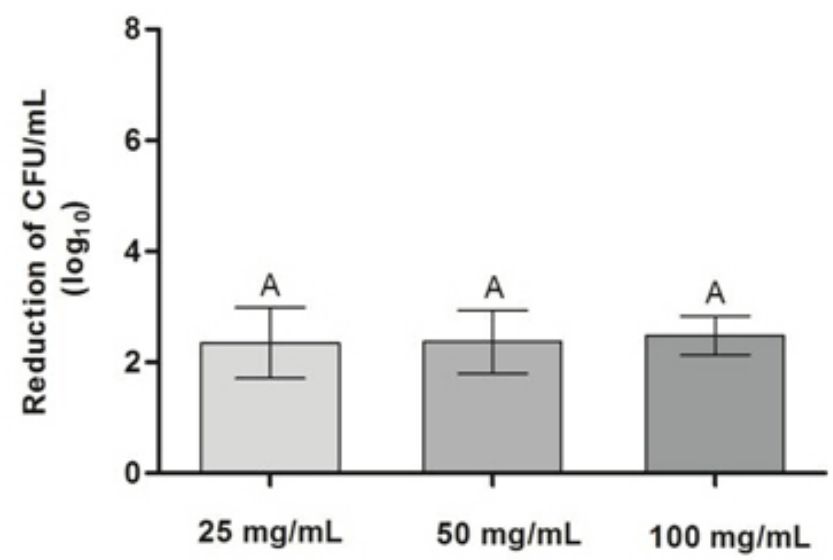

C. dubliniensis

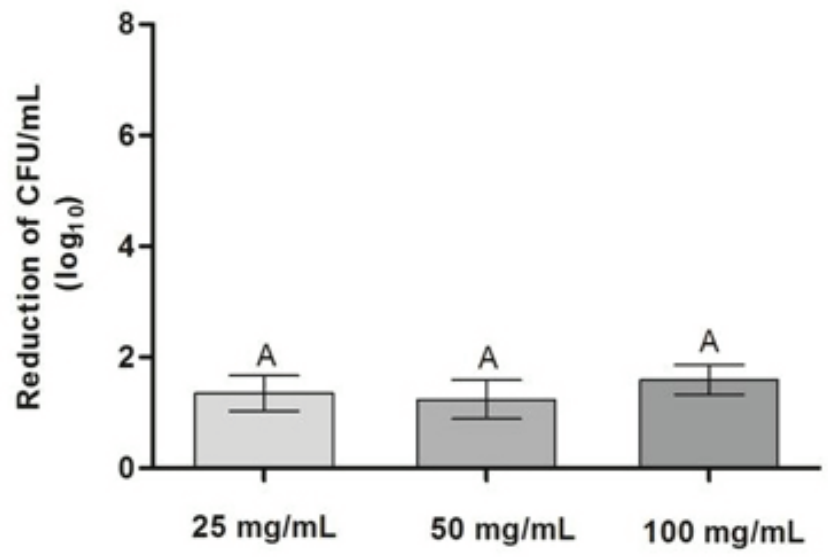

C. krusei

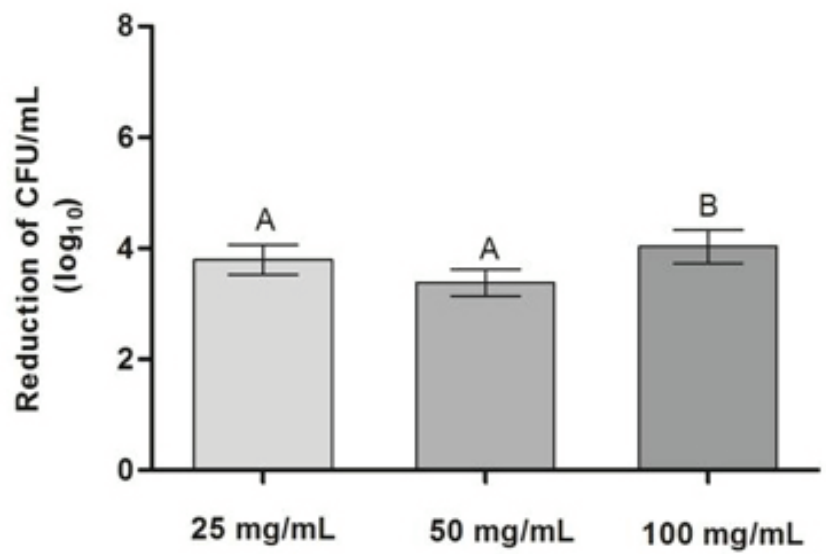

Figure 2 - Mean values ( \pm standard deviation) of reductions (CFU $/ \mathrm{mL}-\log _{10}$ ) of C. albicans, C. dubliniensis, C. glabrata and C. krusei biofilms obtained after $24 \mathrm{~h}$ exposure at 25,50 and $100 \mathrm{mg} / \mathrm{mL}$ of $\mathrm{S}$. terebinthifolius extract, regarding to the control group. Different letters indicate significant statistical difference ( $n=12$; one-way ANOVA and Tukey's test, $P \leq 0.05$ ).

\section{DISCUSSION}

Antifungal effect of $S$. terebinthifolius extract on C. albicans, C. dubliniensis, C. glabrata and $C$. krusei both in planktonic and biofilm forms was demonstrated in the present study. $C$. dubliniensis presented the lowest MIC $(0.39 \mathrm{mg} /$ $\mathrm{mL})$ and MFC $(0.78 \mathrm{mg} / \mathrm{mL})$ values compared to the species analysed like C. albicans (MIC $=1.56 \mathrm{mg} / \mathrm{mL}$; MFC $=3.13 \mathrm{mg} / \mathrm{mL}$ ) and $C$. glabrata and C. krusei (MIC/MFC $=3.13 \mathrm{mg}$ / $\mathrm{mL})$.
The anti-Candida activity of $S$. terebinthifolius has also been reported by some studies using other types of products from this plant. Alves et al. [11] used dye extracted from $S$. terebinthifolius and found antifungal activity on C. albicans (MIC $=0.312 \mathrm{mg} / \mathrm{mL}$; $\mathrm{MFC}=$ $2.5 \mathrm{mg} / \mathrm{mL}$ ). Moura-Costa et al. [12] analysed the aqueous extract of this plant and verified antifungal activity on $C$. albicans (MIC $=0.49$ $\mu \mathrm{g} / \mathrm{mL}$ ), C. parapsilosis (MIC $=3.9 \mu \mathrm{g} / \mathrm{mL}$ ) and C. tropicalis (MIC $=15.6 \mu \mathrm{g} / \mathrm{mL}$ ). These same authors also reported antifungal effect 
of the hydroalcoholic extract on C. albicans (MIC $=0.49 \mu \mathrm{g} / \mathrm{mL})$, C. parapsilosis (MIC $=$ $62.5 \mu \mathrm{g} / \mathrm{mL}$ ) and C. tropicalis (MIC $=62.5 \mu \mathrm{g}$ / $\mathrm{mL}$ ), whereas Alves et al. [13] demonstrated that the dye extracted from $S$. terebinthifolius presented effective action against $C$. tropicalis, with MIC and MFC values of $625 \mu \mathrm{g} / \mathrm{mL}$. Martínez et al. [14] conducted a study with different concentrations of $S$. terebinthifolius alcoholic extract and found no microbial growth inhibition in Gram-positive and Gramnegative bacteria and $C$. albicans at the lowest concentration used (10\%), but an inhibitory effect was observed at higher concentrations (50\% and 100\%). In addition, Gomes et al. [15] reported that lectin, a compound extracted from S. terebinthifolius, had an effect on C. albicans (MIC $=6.5 \mu \mathrm{g} / \mathrm{mL} ; \mathrm{MCF}=26 \mu \mathrm{g} / \mathrm{mL}$ ). Johann et al. [16] demonstrated that $S$. terebinthifolius leaf extract contains saponins, flavonoids, triterpenes, steroids and tannins, all capable of affecting the development of fungal specimens. Studies on plant compounds are necessary to find out bioactive molecules and elucidate their action mechanisms, thus allowing their addition to new drugs.

In this study was also shown the effect of S. terebinthifolius extract on Candida spp. biofilms. Nevertheless, higher concentrations were needed to achieve an effective control of biofilms compared to those used on planktonic forms. In fact, it was reported that biofilms can be more resistant than planktonic cells [17]. C. albicans biofilm exposed to $S$. terebinthifolius extract presented significant reductions of CFU/ $\mathrm{mL}$. However, it was found that concentrations of 100 and $200 \mathrm{mg} / \mathrm{mL}$ were more effective than $50 \mathrm{mg} / \mathrm{mL}$ in $5 \mathrm{~min}$ exposure. Similar reductions of these biofilms were observed after $24 \mathrm{~h}$ exposure to the extract at concentrations of 25,50 and $100 \mathrm{mg} / \mathrm{mL}$. Alves et al. [11] also reported that the dye extracted from $\mathrm{S}$. terebinthifolius showed antibiofilm effect on $C$. albicans demonstrating that the MIC values ( $1 \mathrm{x}$, $2 \mathrm{x}$ and $4 \mathrm{x}$ ) of this product affected significantly this fungal species, causing significant reductions of $\mathrm{CFU} / \mathrm{mL}$ after $60 \mathrm{~min}$ exposure; however they were similar to controls after 120 and
180 min exposures. Barbieri et al. [8] reported inhibitory effect on the initial formation of C. albicans biofilm. According to the authors, this effect can be measured by the presence of some compounds of the plant such as alkaloids, phenols and terpenes. Therefore, it can suggest that this product may be potentially used for both prevention and treatment of infections associated with Candida biofilm formation.

Non-albicans Candida biofilms were also significantly affected such as $C$. dubliniensis, $C$. glabrata and $C$. krusei after $24 \mathrm{~h}$ exposure to different concentrations of $S$. terebinthifolius. There were also significant reductions in $\mathrm{CFU} / \mathrm{mL}$ after $5 \mathrm{~min}$ exposure, except with C. dubliniensis at 50 and $100 \mathrm{mg} / \mathrm{mL}$. These results are important because non-albicans Candida are present in different candidoses such as oropharyngeal candidiasis in HIVinfected individuals [18], invasive candidiasis in intensive care units [19] and vulvovaginal candidiasis [20], including strains resistant to most conventional antifungal like fluconazole and itraconazole.

Similarly to C. albicans, C. dubliniensis can be considered as human commensal yeast and thus can cause opportunistic infections [21]. However, some differences regarding adherence to oral epithelium [22] and filamentation of biofilm cells [23] were related. C. krusei was cited as a pathogen involved in cases of systemic infections, mainly in patients with acquired immune deficiency syndrome [24]. This specie can also inhibit the development of $C$. albicans in an interspecific association [25].

\section{CONCLUSION}

The antifungal potential of the $\mathrm{S}$. terebinthifolius extract suggests opportunities to study this plant more closely so that other possible biological effects (i.e. antibiotic, antitumor and anti-inflammatory) can be explored, including application to cytotoxicity tests to ensure its use in possible formulations, broadening the antifungal therapeutic scope. Thus, it was demonstrated that $\mathrm{S}$. terebinthifolius extract 
presented antifungal effect on C. albicans, $C$. dubliniensis, C. glabrata and C. krusei both in planktonic cultures and biofilms, being of great interest for the development of new antifungal pharmaceuticals.

\section{REFERENCES}

1. PereiraEMR, Gomes RT, Freire NR, Aguiar EG, Santos VR. In vitro antimicrobial activity of brazilian medicinal plant extracts against pathogenic microorganisms of interest to dentistry. Planta Med. 2011;77:401-4. doi: 10.1055/s-0030-1250354.

2. Tsai PW, Chen YT,Hsu PC, Lan CY.Study of Candida albicans and its interactions with the host: A mini review. Biomed. 2013;3(1):51-64.

3. Giri S, Kindo AJ. A review of Candida species causing blood stream infection. Ind J of Med Microbiol. 2012;30:270-8. doi:10.4103/0255-0857.99484. Giri S, Kindo AJ. A review of Candida species causing blood stream infection. Indian J Med Microbiol. 2012;30(3):270-8. doi:10.4103/0255-0857.99484

4. Silva S, Negri M, Henriques M, Oliveira R, Williams DW, Azeredo J. Candida glabrata, Candida parapsilosis and Candida tropicalis: biology, epidemiology, pathogenicity and antifungal resistance. FEMS Microbiol Rev. 2012;36(2):288305. doi:10.1111/j.1574-6976.2011.00278.x

5. Rodrigues CF, Silva S, Henriques M. Candida glabrata: a review of its features and resistance. Eur J Clin Microbiol Infect Dis. 2014;33(5):673-88. doi:10.1007/ s10096-013-2009-3

6. Ferreira GLS, Pérez ALAL, Rocha IM, Pinheiro MA, de Castro RD, Carlo HL, etal. Does scientific evidence for the use of natural products in the treatment of oral candidiasis exist? A systematic review. Evid Based Complement Alternat Med. 2015;2015:147804. doi: 10.1155/2015/147804

7. NocchiSR, de Moura-Costa GF,Novello CR, Rodrigues J,Longhini R, de Mello $\mathrm{JC}$, etal. In vitro cytotoxicity and anti-Herpes simplex virus type 1 activity of hydroethanolic extract, fractions, and isolated compounds from stem bark of Schinus terebinthifolius Raddi.Pharmacogn Mag.2016;12(46):160-4. doi: 10.4103/0973-1296.177903.

8. Barbieri DV, Tonial F,LopezPVA, Sales Maia BH. Antiadherent activity of Schinus terebinthifolius and Croton urucurana extracts on in vitro biofilm formation of Candida albicans and Streptococcus mutans. Arch Oral Biol. 2014;59(9):88776. doi:10.1016/j.archoralbio.2014.05.006.

9. CLSI. Reference method for broth dilution in tests for determining the sensitivity to antifungal therapy of yeast. Approved standard, CLSI document M27-A2.2002. 2nd ed. USA.

10. CLSI. Reference method for broth dilution antifungal susceptibility testing of yeasts. Fourth Informational Supplement M27-S4. 2012. USA.

11. Alves LA, Freires Ide A, Pereira TM, de Souza A, Lima Ede 0, de Castro RD. Effect of Schinus terebinthifolius on Candida albicans growth kinetics, cell wall formation and micromorphology. Acta Odontol Scand. 2013;71(3-4):965-971. do i:10.3109/00016357.2012.741694
12. Moura-Costa GF, Nocchi SR, Ceole LF, de Mello JC,Nakamura CV, Dias Filho $\mathrm{BP}$, et al. Antimicrobial activity of plants used as medicinals on an indigenous reserve in Rio das Cobras, Paraná, Brazil. JEthnopharmacol. 2012:143(2):631638. doi:10.1016/j.jep.2012.07.016

13. Alves LA, Freires Ide A, de Souza TM, de Castro RD. In vitro activity of Schinus terebinthifolius (Brazilian pepper tree) on Candida tropicalis growth and cell wall formation. Acta Odontol Latinoam. 2012;25(3):287-92.

14. Martínez MJ, Alonso GN, Badell JB. Actividad antimicrobiana del Schinus terebinthifolius Raddi (Copal). Rev Cuba Plantas Med. 1996;:137-9.

15. Gomes FS, Procópio TF,Napoleão TH, Coelho LC, Paiva PM. Antimicrobial lectin from Schinus terebinthifolius leaf. J Appl Microbiol. 2013;114(3):672-9. doi:10.1111/jam.12086

16. Johann S, Pizzolatti MG, Donnici CL, Resende MA. Antifungal properties of plants used in Brazilian traditional medicine against clinically relevant fungal pathogens. Braz J Microbiol. 2007;38:632-7.

17. Mah TF,Pitts B, Pellock B, Walker GC, StewartPS, O'Toole GA. A genetic basis for Pseudomonas aeruginosa biofilm antibiotic resistance. Nature 2003:426(6964):306-10. doi:10.1038/nature02122

18. Das PP,Saikia L, Nath R, Phukan SK. Species distribution \& antifungal susceptibility pattern of oropharyngeal Candida isolates from human immunodeficiency virus infected individuals. Indian J Med Res. 2016;143(4):495-501. doi:10.4103/0971-5916.184288

19. Gong X, Luan T, Wu X, LiG, Qiu H, Kang Y, etal. Invasive candidiasis in intensive care units in China: Risk factors and prognoses of Candida albicans and nonalbicans Candida infections. Am J Infect Control. 2016;44:e59-63. doi: 10.1016/j. ajic.2015.11.028

20. Mukasa KJ, Herbertl, Daniel A, Sserunkuma KL, Joel B, Frederick B. Antifungal susceptibility patterns of vulvovaginal Candida species among women attending antenatal clinic at mbarara regional referral hospital, South Western Uganda. Br Microbiol Res J. 2015;5(4):322-31. doi:10.9734/BMRJ/2015/

21. Sullivan DJ, Westerneng TJ, Haynes KA, BennettDE, Coleman DC. Candida dubliniensis sp. nov: phenotypic and molecular characterization of a novel species associated with oral candidosis in HIV-infected individuals. Microbiology.1995;141(Pt7):1507-21. doi:10.1099/13500872-141-7-1507

22. Jackson AP, Gamble JA, Yeomans T, Moran GP, Saunders D, Harris D, et al. Comparative genomics of the fungal pathogens Candida dubliniensis and Candida albicans. Genome Res. 2009;19(12):2231-44. doi:10.1101/gr.097501.109

23. McManus BA, Coleman DC. Molecular epidemiology, phylogeny and evolution of Candida albicans. Infect GenetEvol. 2014;21:166-78. doi:10.1016/j. meegid.2013.11.008

24. Samaranayake YH, Samaranayake LP.Candida krusei: biology, epidemiology, pathogenicity and clinical manifestations of an emerging pathogen. J Med Microbiol. 1994;41(5):295-310. doi:10.1099/00222615-41-5-295

25. Santos JD, Piva E, Vilela SF, Jorge A0, Junqueira JC. Mixed biofilms formed by C. albicans and non-albicans species: a study of microbial interactions. Braz Oral Res. 2016;30.pii:S1806-83242016000100232. doi:101590/1807-3107BOR2016.vol30.0023.

\section{Jonatas Rafael de Oliveira} (Corresponding address)

Anhembi Morumbi University. School of Medicine. Av. Dep. Benedito Matarazzo, 4050, São José dos Campos, SP, Brazil. 12230-002.

Date submitted: 2020 Mar 07 Accept submission: 2020 May 12 